\title{
Brings Happiness to the Lame and the Blind
}

(Note: The following letter to $M r$. and Mrs. E. W. Van Blaricom of Tisdale, was written early in June by Miss Jessie Craig of Victoria, formerly of Tisdale. Miss Melburn, mentioned in the letter, used to lecture in Biology at the University of Saskatchewan and later on was in charge of all nature study in the Junior High Schools for the city of Ottawa. She is now retired and is living in Victoria. She has never lost her keen interest in our feathered friends.)

"A nice looking beautifully coiffed, stylishly dressed helplessly-crippled lady occasionally comes into the store. Recently she asked if I knew of any book that would help one to identify bird songs. She wanted the information for a blind and paralyzed young chap at the Veterans Hospital. (She herself has no use of her feet and legs and navigates by means of crutches).

I got in touch with Miss Melburn who immediately provided much information as to books and records. More-she took the lady seeking information and her blind friend into the woods.

Next day the crippled lady phoned me and a happier voice I've never heard! She didn't list her accomplishments but she explained that her friend had learned to recognize the songs of nine birds and that Miss Melburn is taking them out again - next time to the grounds of Government House. There are lovely trees there; it is probably rich in birds. I pass on the thanks of the lame and the blind."

\section{Spring and Summer Migrations}

By William Niven, Sheho.

$\mathbf{O}^{\mathrm{w}}$ WING to the heavy snowfall and rains this spring, most of the small sloughs are full even now, though some of the larger lakes have a long way to go yet to attain the high levels they once had. For this reason all waterfowl and birds that live around water are quite plentiful. In some cases, such as the .Yellowheaded Blackbird, greater numbers are here than have been seen for years. All the common species of ducks are quite plentiful.

Some of the land birds did not appear plentiful in migration this spring. The sparrows, such as the Junco, White-throated, and Whitecrowned were very few in numbers as compared to other years. Also the warblers had a poor year. At least I saw very few except Yellow Warblers which are always common. This may have been because the weather was warm in May and they may have passed through without stopping.

Large flocks of Lapland Longspurs and also those northern species of
Horned Larks (possibly "Hoyt's") were seen sometimes together on the fields during the first three weeks of May. The fields were fairly covered with them while they were here. While the Tree Swallows came about the usual time, May 1, the Barn Swallows were later than usual May 18. Brown Thrashers arrived before their usual time, May 5 , but the Catbirds did not show up till May 28-a very late arrival for them.

The ones noted as first seen during June were Cedar Waxwing, June 8, about a week late; Black-billed Cuckoo, June 12, sometimes not seen at all; Bobolink, one only, June 25; Ruddy Ducks, two only June 25 they have been very scarce during the last few years; Leconte's Sparrows-a pair found nesting June 26; Least Flycatcher, scarce this season. These last four species had probably been here for some time but, being scarce, are only seen in certain places.

Probably you, have alieady heard (Concluded on page 9 ) 